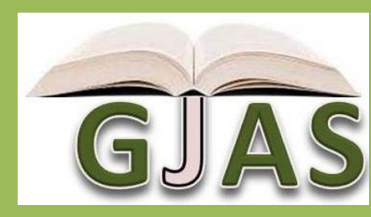

\title{
Agricultural Water Management in Sub - Sahara Africa: Options for Sustainable Crop Production
}

\section{Agada Odu Odo}

Department of Crop Science, Faculty of Agriculture, Unversity Putra, Malaysia,43400, Serdang, Selangor.

\section{ARTICLE INFO}

Article No.: 022616046

DOI: 10.15580/GJAS.2016.4.022616046

Submitted: $26 / 02 / 2016$

Accepted: 07/02/2016

Published: 25/04/2016

${ }^{*}$ Corresponding Author

Agada Odu Odo

E-mail: anreaeryck@gmail.com

Keywords:

Water harvesting, In-field water

management, Sub-Saharan

Africa, Water management,

Poverty trap

\section{ABSTRACT}

In spite of her vast resource base, the majority of the population of Sub - Saharan Africa remain in a poverty trap engendered largely by poor agricultural productivity. One of the culprits for this consistently low agricultural performance is the poor management of her agricultural water resources. This paper reviews the current state of agricultural water management in the region and considers a number of the options available for sustainable intensification. The paper advocates an enlightened development of irrigation as part of a new perspective for improving rainfed agriculture. This perspective considers it a waste to seek system sustainability and resilience whilst the key players are incapacitated by poverty. The paper, therefore, recommends that any policy or strategy for productivity growth must be driven by the primary goal of empowering farmers as the main focus and not just a by-product of productivity improvement. To achieve this, improving water management in rainfed system appears the best option. 


\section{LIST OF ABBREVIATIONS}

$\begin{array}{lll}\text { IFAD } & - & \text { International Fund for Agricultural Development } \\ \text { WRI } & - & \text { World Resource Institute } \\ \text { IAASTD } & - & \text { International Assessment of Agricultural knowledge, Science and Technology for Development } \\ \text { ICBA } & - & \text { International Center for Biosaline Agriculture } \\ \text { CAADP } & - & \text { Comprehensive Africa Agricultural Development Programme } \\ \text { NEPAD } & - & \text { New Partnership for Africa's Development } \\ \text { MENA } & - & \text { Middle East and North Africa } \\ \text { UNDP } & - & \text { United Nation Development Programme } \\ \text { HLPE } & - & \text { High-Level Panel of Experts } \\ \text { IFPRI } & - & \text { International Food Policy Research Institute } \\ \text { IFWM } & - & \text { Institute for Forest and Watershed Management }\end{array}$

\section{INTRODUCTION}

In the next 35 years, agriculture, particularly in Sub Saharan Africa would be facing one of its major challenges - that of meeting the food need of a growing population (Zuberi and Thomas, 2012). On the global scale it is estimated that to achieve food security would require either a doubling or close to a doubling of current food production levels (IFAD, 2012; World Resource Institute (WRI), 2013), a target that may still leave 1 in 20 people undernourished in sub - Saharan Africa (FAO, 2011). One serious challenge to this goal is the level of resources that would be required to achieve it.

Among the resources that are expected to come under great pressure is water. According to Rockstrom et al, (2010), the food water requirement projection for 2050 is between 8500 to $11,000 \mathrm{~km}^{3} /$ year. This colossal food water requirement is a cause for concern in view of the dwindling global water fortune. It is projected (Fig. 1), that by 2025 , half of the world would experience some form of water scarcity (Escobar, 2010) and that by 2050 , about $46 \%$ of the world population would be facing food scarcity due to water inadequacy (Falkenmark, 2013).

Sub - Saharan Africa is particularly in a precarious situation. The sub-region suffers from serious cases of rainfall variability, including cases of dry spells, poor rainfall distribution and outright drought (Makurira $\left.\begin{array}{llll}2 & 0 & 1 & 0\end{array}\right)$. According to Makurira, (2010) rainfall variability is one of the major reasons for low agricultural productivity. It has also been suggested that rainfall variability is part of the reasons for farmer's reluctance to invest in much-needed input (Rockstrom et al., 2010). Added to this is the fact of her increasing population and the pressure which it would invariably place on water resources. It has been predicted that by 2050 Africa's population will reach the two billion mark, which is more than 2.6 times the current population (Mulira, 2010 in Besada and Werner, 2015). The fact that more than half the population of sub-Saharan Africa relies on agriculture (International Center for Biosaline Agriculture, 2015) and with an undernourishment prevalence of 24.8 $\%$ (FAO, 2013), the necessity of facing up to the water challenge becomes more urgent. According to the UNDP, water scarcity would be the largest singular contributor to future food insecurity (Du Toit, 2011 cited in Besada and Werner, 2015). The point bears stating however that the region's water crisis is in most cases not the result of absolute scarcity but mostly the result of poor management. What is required then is the deft management of the region's water resources, to drive agricultural intensification and build resilience.

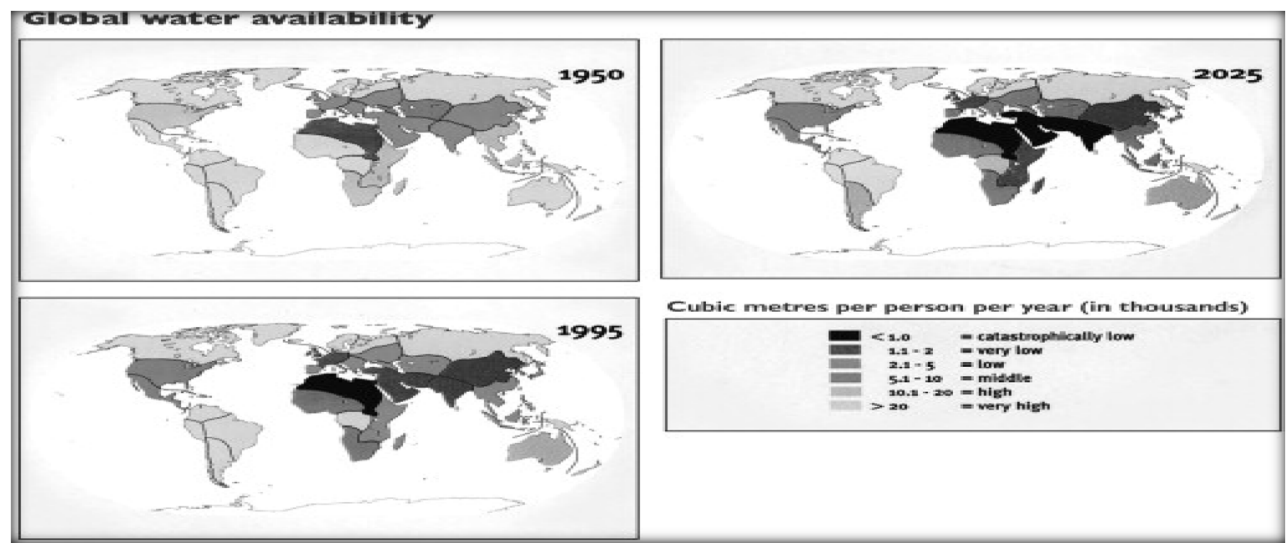

Fig. 1: Global water availability by 2025

Source: Escobar, 2010 


\section{REVIEW}

\section{The global water outlook and agriculture: perspective on sub - Sahara Africa}

Current water challenges, though global are more pronounced in some areas than others. Rockstrom et.al (2010) project that by 2050 , water scarcity would become a serious problem throughout the MENA (The Middle East and North African) countries, South Asian states and some sub-Saharan African countries such as Malawi, Rwanda, Burundi and Uganda. Indeed, the African continent is among the most threatened. The International Assessment of Agricultural knowledge, Science and Technology Development (IAASTD), projects that by 2025 at least 23 African countries would be among countries facing severe water shortages (IAASTD, 2009 cited in Besada and Werner, 2015). Besada and Werner (2015), considers growing pressure on scarce water resources as one of the most important factors threatening Africa's agriculture and food security. According to the International Center for Biosaline Agriculture (ICBA), 'water scarcity and degradation due to soil nutrient depletion and soil salinization are the most potent threat to small-scale farming in sub-Saharan Africa' (ICBA,2015).

Africa's increasing water vulnerability is driven by a number of factors including climate change. According to IPCC (2007), drought, dry spells and flooding will become more frequent and intense in subtropical areas as a consequence of climate change. 'Already, Africa is seeing worsening incidence of increasing precipitation in wet months, decreasing precipitation in dry months, increased desertification, reduced river flow, increased risk of flash flooding and decline in long -cycle crop production' (Besada and Werner, 2015). Okoloye et al (2012), working in Nigeria, reported that 'climate variability has resulted in a shorter rainfall duration due to shift in period of onset and cessation, general increase in mean temperature, shift in onset and duration of little dry season, decreasing rain days and increasing dry spells during the raining season'. Dramatic pointers to the devastating potential of Africa's increasing drought profile dot her landscape here and there. A recent case in point is the Horn of Africa where increased drought in 2011resulted in a huge humanitarian crisis that affected close to 13 million people (Besada and Werner 2015). Ludi (2009) noted a report by the Overseas Development Institute which predicted that climate-induced changes will reduce SubSaharan African countries cereal production potential by a factor of up to $12 \%$ and put approximately $40 \%$ of them 'at risk of significant declines in crop and pasture production. Apart from climate change, other major factors significantly impacting water availability are urbanization and industrial growth (Zuberi and Thomas, 2012). In Africa, urban cities are expanding at an alarming rate, giving her the reputation of having the fastest growing urban populations in the world (Besada and Werner 2015, Hanson, 2007). According to UN Habitat (2010), by 2050 Africa's urbanization would be in the range of $60 \%$. In real figures, this means about 1.23 billion people, more than double the estimated population of 2 billion living in major cities, compared to the current figure of about 300,000 . Urbanization comes with changes in dietary demand. Water required to supply the urban growth and new eating habit would put serious pressure on water resources. Coupled with climate change, these constitute a formidable threat to the region's precarious water and food situation.

\section{Water management options for sustainable crop production in sub-Saharan Africa}

The assertion that irrigation is a major culprit of the growing global water crisis is not exactly the case with sub - Saharan Africa. This is because irrigation farming is currently at a low level in sub - Sahara Africa, accounting for just about $5 \%$ of agricultural production, making sub - Saharan Africa the region with the poorest irrigation ratio in the world (Africa Infrastructural Knowledge, 2011). Asia and Latin America has 37\% and $14 \%$ ratio respectively (You et al., 2011). Peacock and Ward (2007) observed that of the fifteen farming systems identified in the region, only one is predominantly irrigated and this covers just $1 \%$ of the land area and 2 $\%$ of the farming population. Of the total freshwater withdrawals, You et al (2011) reported that only $1 \%$ is used in agriculture. They maintain that Africa's extensive ground water resources remain largely untapped (Table 1 and 2). 


\begin{tabular}{|c|c|c|c|c|c|}
\hline Region & $\begin{array}{l}\text { Share of cultivated } \\
\text { area equipped for } \\
\text { irrigation }\end{array}$ & $\begin{array}{l}\text { Agricultural } \\
\text { water withdrawal } \\
\text { as share of total } \\
\text { renewable water } \\
\text { resources }\end{array}$ & $\begin{array}{l}\text { Dam capacity as } \\
\text { share of total } \\
\text { available surface } \\
\text { water }\end{array}$ & $\begin{array}{l}\text { Ground water } \\
\text { pumped as } \\
\text { share of total } \\
\text { renewable } \\
\text { ground water }\end{array}$ & $\begin{array}{l}\text { Value of irrigated } \\
\text { output as share } \\
\text { of the total value } \\
\text { of agricultural } \\
\text { output }\end{array}$ \\
\hline Northern Africa & 28.1 & 218.6 & 203.8 & 306.7 & 86.2 \\
\hline SSA average & 3.5 & 1.3 & 11.2 & 17.5 & 24.5 \\
\hline Africa average & 5.8 & 3.3 & 14.6 & 72.9 & 37.7 \\
\hline World average & 17.7 & 5.2 & 7.6 & $n / a$ & $n / a$ \\
\hline
\end{tabular}

1. Area equipped for irrigation relates to area with technical irrigation facilities, not all area equipped for irrigation necessarily receives irrigation water.

2. Total renewable water resources include the surface and ground water resource volume renewed each year in each country/region.

3. $\mathrm{n} / \mathrm{a}=$ not available; SSA = Sub-Saharan Africa. Source: Svendsen et al. (2009), a bridged.

Table 2: Global survey of groundwater irrigation

\begin{tabular}{|l|l|l|}
\hline \multirow{2}{*}{ REGIONS } & GROUND WATER IRRIGATION \\
\cline { 2 - 3 } & M/ha & Proportion total \\
\hline Global total & 112.9 & $38 \%$ \\
\hline South Asia & 48.3 & $57 \%$ \\
\hline East Asia & 19.3 & $29 \%$ \\
\hline South-East Asia & 1.0 & $5 \%$ \\
\hline $\begin{array}{l}\text { The Middle East } \\
\text { and North America }\end{array}$ & 12.9 & $43 \%$ \\
\hline Sub-Saharan Afr & 0.4 & $6 \%$ \\
\hline \multicolumn{2}{|c|}{ Source: HLPE 2015 (Abridged) }
\end{tabular}

Two important reasons why there is a growing advocacy for irrigation farming in sub - Sahara Africa are the fact of its greater production efficiency (Africa Infrastructural Knowledge, 2011) and sub - Sahara Africa's great vulnerability to weather vagaries. Globally, irrigation produces about $40 \%$ of food supply from just about 18 $\%$ land area being irrigated (You et al, 2011). In sub Sahara Africa, rain-fed agriculture is currently the most widely practiced form of agriculture and accounts for 93 $\%$ of production (UNDP, 2012). Rain - fed agriculture is highly sensitive to climate variability (Ewona, Osang and Udo, 2014), as such a wholly weather dependent production system would be quite unsustainable. It has been suggested that variability is one of the reasons for the consistent low yield of the region's agriculture (Rockstrom et al., 2010). Vargas Hill and Viceisza (2011) and Binswanger-Mkhize (2010) implicated it as a major disincentive for investment in yield-enhancing technologies. It would, therefore, require some form of irrigation to meet sub - Sahara Africa's food need. It is not surprising then that there has been a resurgence of interest in irrigation in the sub-region (HLPE report 2015).

Xie et al (2013) reported that there is a growing interest in irrigation in SSA, with the international agricultural development community promoting investment in the sector. For example, the Comprehensive Africa Agriculture Development program's (CAADP) pillar 1, under the African Union
(AU) and the New partnership for Africa's Development (NEPAD) has irrigation as a key investment priority (You et al., 2011). A number of researchers have noted the great potential for growth in irrigation and productivity in SSA agriculture. Xie et al., (2013) showed that there is an area expansion potential of 30 million hectares, with a capacity to benefit up to 369 million people and generate up to 22 million dollars annually. You et al., (2011) on the other hand found a 24 million ha profitable expansion potential. They submitted that "the potential for irrigation development for Africa generally, and particularly in subSaharan Africa is large, given existing water resources, the high value of irrigated agriculture on the continent, and the large number of rural poor that could benefit from productivity enhancement as a result of irrigation investment". In tandem with this submission, IAASTD (2009) and FAO (2011) opined that agricultural intensification, with irrigation playing a central role, will underline future growth in crop production in the developing world. In spite of this great potential, progress over the last 40 years has been slow (Africa Infrastructural Knowledge, 2011).

It bears remarking therefore that the issue of irrigation potential, as heartwarming as it is, be approached with the guidance of regional peculiarities. This writer believes that there should be a phased or enlightened implementation of sub - Sahara Africa's agricultural water management options, which must take into account current capacity, particularly of the farmers, 
in terms of technical and financial capacity, the state of infrastructure and capacity to develop them and the need for ecological safeguards. In North Africa where irrigation has been pursued more vigorously and in other places, important lessons of how irrigation can go wrong abound and should serve as a useful guide. You et al (2011) observed that extensive and unsustainable irrigation practices in North Africa have resulted in overexploitation of ground water, a situation which, according to FAO has become a constraint to economic development (IFPRI 2010). Of course, the effect of such extensive abstraction on ecosystem functions cannot be over emphasized. Dile et al (2013) in their advocacy for water harvesting as the ideal strategy for intensification and resilience, opined that unsustainable agricultural water use is a major culprit of soil degradation, groundwater depletion, water pollution, and waterrelated ecosystem degradation. Apart from this, the investment required to drive new projects and renew old ones may not be immediately available for most sub Saharan African countries, which currently suffer a huge agro-related infrastructural deficit (Besada and Werner 2015). Gajigo and Lukoma (2011) and PinstrupAnderson and Simokawa, (2006) opined that infrastructure is a major determinant of agricultural productivity, chiefly because it would reduce the cost of input and output market. They also report that the subregion suffers from a dearth of agricultural infrastructure including irrigation, roads and storage facilities. A number of studies on irrigation show that not only is the level of infrastructural development low, it is also growing at a very slow pace (Gajigo and Lukoma,2011).

Another significant disincentive to irrigation development is access to market. When this is coupled with the fact that about $40 \%$ of the population of subSaharan Africa lives in landlocked areas which according to the HLPE (2009) adds about $77 \%$ as cost of transportation to the value of export, one gets a good idea of the level of infrastructural development that needs to take place before investment in irrigation can make the desired impact.

Other major considerations for irrigation development would be the viability status of the crop to be irrigated, possibility of crop price decline and climate change impact on water availability for irrigation (IPCC, 2007 cited in Rockstrom et al., 2010). Rice, high-value horticultural crops and industrial crops such as sugar cane and cotton are adjudged to be the most viable (peacock, Ward and Gambarelli, 2007). Even then such viability is relative and depends on a number of factors. For example, the viability of rice depends largely on the investment cost, the possibility of crop intensification that would procure yield of up to $6 \mathrm{tha}^{-1}$ and permit double cropping and a production targeted at import substitution (peacock, Ward and Gambarelli, 2007).

Whereas the renewed interest in irrigation in Sub-Saharan Africa must be pursued to its logical conclusion, it is pertinent that this renewed zeal be steered by a whole new philosophy that approaches irrigation more as a business rather than a development project. This will help to define the value of subsidy and so called aid, vis-à-vis the sustainability and competitiveness of projects, the scale of projects (whether small, medium or large scale) or its necessity. Such an approach will create the environment that will make it easy for farmers to take responsibility for such schemes.

This writer suggests that the initial focus of water management strategy should be to put a system in place that is relatively easily accessible and low cost, with possibility for widespread impact on a short run and high resilience value. Such a system should empower farmers and whole communities, enhancing their capacity to become major players in prosperous farming, including private irrigation ventures. Indeed, it is advocated that focus should be shifted from yield or food security to the liberation of the farmer from the poverty trap. National or regional agricultural policies, yield improvement programs and food security agenda should be designed to empower resource-poor farmers as a strategic first step towards attaining sustainability and resilience. Such a possibility appears to be more readily achievable on dry land systems.

According to Rockstrom et al (2010), the possibility of a global water crisis underlines the need to commit to effective management of water in rainfed agriculture. This is because it has a large potential for productivity enhancement and the building of resilience.

A major factor influencing the productivity of dryland systems is weather vagaries. As already stated, rainfall vulnerability not only impacts yield but serve as a significant disincentive to investment in input. Makurira (2010) implicated dry spell occurrences as the major cause of crop failure in SSA. He pointed out that there are between 10 to 21 dry spell occurrences every year in SSA. It bears saying therefore that even though dry spells appear to have attracted little attention (Makurira, 2010), the spell must be broken if meaningful progress in agricultural productivity is to be made. What is required then are strategies that would bridge vital moisture gaps caused by such dry spells.

Bridging such gaps in rainfed agriculture or dry land farming holds great prospect for the following reasons. Firstly, rainfed farming is what farmers are already used to. According to the World Bank Group (2015), rainfed farming accounts for about $96 \%$ of the cropland in sub- Saharan Africa. Investing in rainfed farming is, therefore, a case of meeting the farmers where they are and improving what they are already doing. A greater implication is the fact that a large part of the population is imparted within a short time. Most importantly, however, is the fact that there is a huge yield gap (Dzanku, Jirstrom and Marstorp, 2015) in sub Saharan Africa's rainfed system that if exploited would not only improve food security situation but significantly impact the regions embarrassing poverty index. Dzanku et al (2015) opined that poverty increases with yield gap. According to Oweis (1997) cited in Rockstrom et al 
(2010), effective management of water in rainfed systems could improve yield by as much as $400 \%$ in arid regions as was observed in Syria. It is estimated that the average cereal yield in sub-Saharan Africa is around one (1) ton ha ${ }^{-1}$, a figure which is less than half of what a farmer produces in India and a fifth of what an American farmer gets (World Bank, 2007). With regard to poverty, it has been asserted that more than any other sector, productivity change in agriculture has the greatest immediate effect on poverty (Gajigo and Lukoma, 2011; Pinstrup-Anderson and Shimokawa, 2006). Christiensen, Demsey and Kuhl (2011) estimated that every $1 \%$ increase in agricultural productivity reduces poverty five times. Dzanku et al (2015) concluded that the potential effect of closing the current yield gap on poverty in sub- Saharan Africa is enormous.

Another important justification is the impact of a more efficient rainfed system on the availability of water for other competing sectors. According to Kijne et al (2009) cited in Makurira (2010), productivity increase in rainfed agriculture would free up about $2200 * 10^{9} \mathrm{~m}^{3}$ of water for other sectors. This is important in a region where projections portend the likelihood of either economic or physical water scarcity by 2025 (Makurira, 2010).

Furthermore, the future speaks of the possibility of losing some of the area currently committed to rainfed farming to further degradation and climate change (Lane and Jarvis, 2007 cited in Alliance for Green Revolution in Africa 2014 and Falkenmark and Rockstrom, 2008 cited in Dile et al 2013).

Options for improving rainfed agriculture include those that either increase plant water availability or increases plant water uptake capacity. Principally, they include water harvesting strategies which are implemented in two broad subtypes either as ex-situ or in-situ strategies. Also included is the in-field management of water using strategies that include soil conservation practices to optimize their availability for crop use. Considering that the general aim is to, among others mitigate dry spells and enable off - season moisture availability, it is suggested that all strategies for water availability be accommodated. The efficacy of each of these water management strategies in improving productivity in rainfed systems was highlighted by a number of workers. Oweis and Hachum (2006) reported a $2 \mathrm{~kg}$ increase in wheat grain yield for every $2 \mathrm{~cm}^{3}$ of extra water made available through supplemental irrigation. Kayombo, Hatibu and Mahoo (2004), also reported a 120 to $150 \%$ increase in maize grain yield with water harvesting strategy in Tanzania. Anderson, Zehnder, Rockstrom and Yang (2011), also reported that soil moisture enhancement occasioned by the implementation of in-situ water harvesting improved yield stability of small holders in the Thukela river basin in South Africa. In-field water management has been shown to have significant effect on soil moisture and yield. Makurira (2010) working with maize in the Makanya catchment in Tanzania combined conservation agriculture practices and ex-situ water harvesting with some traditional in-field soil moisture enhancement strategies, such as soil bunding (fanya juu) and found that there was an increase in transpiration value of about $49 \%$ and a yield of $4.8 \mathrm{t} \mathrm{ha} / 1$ against $0.2 \mathrm{t} \mathrm{ha} / 1$ obtainable under the normal farming system.

\section{CONCLUSIONS}

This review has indeed shown that there is scope for productivity improvement through proper management of water resources. It is, therefore, pertinent to submit that because smallholder farmers, who constitute the larger percentage of SSA farming population are already locked in a poverty trap, their liberation must form the foremost and fundamental bedrock of any effort at solving the region's food challenge. This paper submits that the focus should be the farmer, not the yield, not food security because as long as $80 \%$ of those who produce $96 \%$ of the food in SSA remain in the poverty trap which agriculture has become for them, no policy or program aimed at yield improvement would be sustainable. It is in this regard that the use of in- field water management, employing all forms of water harvesting strategies together with supplemental irrigation, where necessary and available, as a strategic water management option in rainfed systems to remove one of the major obstacles to productivity is advocated.

\section{REFERENCES}

Africa Infrastructural Knowledge (2011). Africa's agricultural productivity is the lowest in the world-in part because of the underuse of irrigation. Retrieved from www.infrastructureafrica.org/sectors/irrigation.

Anderson JCM, Zehnder AJB, Rockström J, Yang H (2011). Potential impacts of water harvesting and ecological sanitation on crop yield, evaporation and river flow regimes in the Thukela River basin, South Africa. Agricultural Water Management 98: 11131124.

Besada $\mathrm{H}$ and Werner $\mathrm{K}$ (2015). An assessment of the effect of Africa's water crisis on food security and management. Int. J. wat. Res. Dev. 31(1)120-133; doi: 10.1080/07900627.2014.905 124.

Christiensen L, Demsy L and Kuhl J (2011). The (evolving) role of agriculture in poverty reduction-an empirical perspective. Journal of Development Economics 96, 239-254.

Dile TY, Karlberg L, Temesgen $\mathrm{M}$ and Rockstrom $\mathrm{J}$ (2013) The role of water harvesting to achieve sustainable agricultural intensification and resilience against water related shocks in sub- Saharan Africa. Agric. Ecos. Environ. 181: 69-79.

Du Toit DC (2011). Food security (General report of Directorate of Economic Services, Production Economies Units, Department of agriculture, forestry and fisheries, South Africa). http://www.nda.agric.za/docs/../foodsecurity. 
Dzanku FM, Jirstrom M and Marstorp H (2015) Yield gap- based poverty gaps in rural sub- Saharan Africa. World development, 67: 336-362.

Escobar IC (2010). An overview of the global water situation. Sustainability Science and Engineering, 2.3-5. doi:10.1016/s1871-2711(09)00201-3.

Ewona I O, Osang J E, Udo S O (2014). Trend analyses of rainfall patterns in Nigeria using regression parameters; International Journal Of Technology Enhancements And Emerging Engineering Research. 2(5): 129 Issn 2347- 4289.

Falkenmark, M (2013). Growing water scarcity in agriculture: Future challenge to global water scarcity. Physiological Transactions of Royal Society, 1-14. doi:10.1098.2012.0410.

Falkenmark M and Rockström J (2008). Building resilience to drought in desertification-prone savannas in Sub- Saharan Africa: the water perspective. Natural Resources Forum 32, 93-102.

FAO. (2011). The State of the World's Land and Water Resources for Food and Agriculture (SOLAW)Managing Systems at Risk.

FAO (2013). The state of food insecurity in the world- the multiple dimensions of food security. http://www.fao.org/docrep/018/i3434e/i3434e.pdf.

Gajigo $O$ and Lukoma $A$ (2011). Infrastructure and agricultural productivity in Africa. Retrieved from www.afdb.org/fileadmin/uploads/afdb/Documents.

Hanson S (2007). Urbanization in sub-Saharan Africa. Retrieved from http://www.cfr.org/africa-subsaharan/urbanization.

HLPE (2015). Water for food security and nutrition. A report by the High-Level Panel of Experts on Food Security and Nutrition of the Committee on World Food Security, Room 2015. www.fao.org/cfs/cfshlpe.

International Assessment of Agricultural Knowledge, Science and Technology for Development (IAASTD). (2009).Sub-Saharan Africa (SSA) report, Mclntyre $\mathrm{BD}$, Herren HR, Wakhungu $\mathrm{J}$ and Watson RT (Eds). Washington, DC: Island Press In Besada $\mathrm{H}$ and Werner K (2013) An assessment of the effect of Africa's water crisis on food security and management. Int. J. wat. Res. Dev. 31(1)120-133; doi: 10.1080/07900627.2014.905 124.

International Center for Biosaline Agriculture (2015). Training: Soil Salinity and Soil Fertility Management in Africa. http://www.biosaline.org/content/trainingsoil-salinity-and-soil-fertility

International Fund for Agricultural Development (IFAD) 2012. The future of world food and nutrition security: investing in smallholder agriculture- an international policy. Retrieved from www.rurlpovertyportal.org

IFPRI (2010) Irrigating Africa www.ifpri/org.blogs

IPCC, (2007): Climate Change (2007) The Physical Science Basis.Contribution of Working Group I to the Fourth Assessment Report of the Intergovernmental Panel on Climate Change, S. Solomon D, Qin M, Manning Z, Chen M, Marquis
KB, Averyt M, Tignor and Miller HL, Eds., Cambridge University Press, Cambridge, UK.

Kayombo B, Hatibu N and Mahoo HF (2004). Effect of micro-catchment rainwater harvesting on yield of maize in a semi - arid area. ISCO. $13^{\text {th }}$ international Soil Conservation Organisation Conference Brisbane, July 2004.

Kijne JW, Barron J, Hoff H, Rockström J, Karlberg L, Gowing J, Wani SP, and Wilchens D (2009). Opportunities to increase water productivity in agriculture with special reference to Africa and South Asia. Project report, Stockholm Environmental Institute, Stockholm. Retrieved from http://www.seiinternational.org/publications?pid=1239.

Lane A and Jarvis A (2007). Changes in climate will modify the geography of crop suitability: Agricultural biodiversity can help with adaptation. Journal of the Semi-Arid Tropical Agricultural Research, 4(1).

Ludi, E. (2009).Climate change, water and food security. Background Note. London: Overseas Development Institute In Besada H and Werner K (2013) An assessment of the effect of Africa's water crisis on food security and management. Int. J. wat. Res. Dev. 31(1)120-133; doi: 10.1080/07900627.2014.905124.

Makurira H (2010) Redrawing the rainbow of water to achieve food security in smallholder rainfed systems (Doctoral Dissertation). Retrieved from http://www.repository.tudelft.nl.

Mulira P (2010). Africa: Population explosion. Africa is sitting on a time bomb Analysis from allAfrica. Retrieved from http://allafrica.com/stories/201004010036.html.

Okoloye CU, Aisiokuebo NI, Ukeje JE, Anuforom AC and Nnodu ID (2013) Rainfall variability and the recent climate extremes in Nigeria. Retrieved from http://africaclimateconference.org/wpcontent/uploads/2013/11/B4- 03_OKOLOYE.pdf,

Oweis T, Hachum A, (2006). Water harvesting and supplemental irrigation for improved water productivity of dry farming systems in West Asia and North Africa. Agricultural Water Management 80: 57-73.

Oweis T (1997). Supplemental irrigation: a highly efficient water-use practice.

International Center for Agricultural Research in the Dry Areas, Aleppo, Syria In Rockstrom J, Karlberg L, Wani P.S, Barron J, Hatibu N, Oweis T, Bruggeman A, Farahani J and Qiang Z (2010) Managing water in rainfed agriculture- the need for a paradigm shift. Agric. Water management. 97(2010): 543-550.

Peacock T, Ward C and Gambarelli G (2007) Investment in agricultural water for poverty reduction and economic growth in Sub- Saharan Africa (a collaborative program of $A D B, F A O, I F A D, I W M I$ and WORLD BANK) http://www.siteresources.worldbank.org/..synthesisre port. 
Pinstrup-Anderson P and Shimokawa S (2006). Rural infrastructure and agricultural development. Retrieved from. http://www. siteresources. worldbank.org.

Rockstrom J, Karlberg L, Wani P.S, Barron J, Hatibu N, Oweis $\mathrm{T}$, Bruggeman A, Farahani $\mathrm{J}$ and Qiang $\mathrm{Z}$ (2010) Managing water in rainfed agriculture- the need for a paradigm shift. Agric. Water management. 97(2010): 543- 550

Svendsen S, Ewing M and Msangi S (2009). Measuring irrigation performance in Africa. IFPRI Discussion Paper 894. Washington, D.C.: International Food Policy Research Institute.

The world Bank Group (2015). Rainfed agriculture www.worldbank.org/../rainfed-agric

UN Habitat. (2010). The state of African cities 2010: Governance, inequality and urban land markets. Retrieved from www.unhabitat.org.

World Bank (2007). Africa region: Irrigation business plan. Revised draft. Washington, D.C. In You L, Ringler C, Wood-Sichra, Robert R, Stanley W, Zhu T, Nelson G, Guo Z nd Sun Y (2011) What is the irrigation potential for Africa? A combined biophysical and socioeconomic approach. Food policy. 36(6): 770-782.

World Resource Institute (2013). Creating a sustainable food future: Interim findings (a menu of the solution to sustainably feed more than 9 billion people by 2050). Retrieved from www.wri.org/../wri13_report.

Xie H, You L, Wielgosz B and Ringler C (2013) Estimating the potential for expanding smallholder irrigation in Sub- Saharan Africa. Agric. Water management. 131(1): 183-193; doi: 10.1016/j.agwat.2013.08.011.

You L, Ringler C, Wood-Sichra, Robert R, Stanley W, Zhu T, Nelson G, Guo Z nd Sun Y (2011) What is the irrigation potential for Africa? A combined biophysical and socioeconomic approach. Food policy. 36(6): 770-782.

Zuberi T and Thomas KJA (2012). Demographic Projections, the Environment and Food Security in Sub-Saharan Africa. http://www.undp.org/content/dam/rba/docs/Working \%20Papers/Demographic\%20Projection. 